Удк 351

А. О. Гричишен,

д. е. н., професор, декан факультету публічного управління та права, Аержавний університет " Житомирська політехніка"

ORCID ID: 0000-0001-5484-6421

I. B. Суирунова,

к. е.н., дочент, дочент кафедри економічної безпеки, публічного управління та адміністрування, Аержавний університет "Житомирська політехніка" ORCID ID: 0000-0001-5484-6421

C. П. Аисак, здобувач кафедри інформачійних систем в управлінні та обліку, Аержавний університет " Житомирська політехніка"

ORCID ID: 0000-0001-7718-1207

DOI: $10.32702 / 2306-6814.2020 .24 .140$

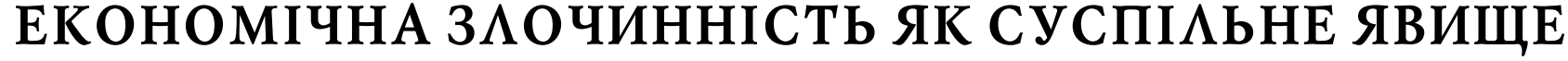 ТА ЗАГРОЗА АЕРЖАВНІЙ БЕЗПЕЦІ
}

\author{
D. Grytsyshen, \\ Doctor of Economic Sciences, Professor, The Dean of the Faculty of Public Administration and Law, \\ Zhytomyr Polytechnic State University \\ I. Suprunova, \\ $\mathrm{PhD}$ in Economics, Associate Professor, Associate Professor of the Department of Economic Security, \\ Public Administration and Management, State University "Zhytomyr Polytechnic" \\ S. Lysak, \\ Candidate for a degree of the Department of Management Information Systems \\ and Accounting, Zhytomyr Polytechnic State University
}

\section{ECONOMIC CRIME AS A SOCIAL PHENOMENON AND A THREAT TO STATE SECURITY}

\begin{abstract}
Метоюдержавного управління є врегулювання економічних інтересів у суспільстві, що дозволить певним чином запобігти економічній злочинності, забезпечить дотримання правопорядку, що дозволяє уникнути конфлікту економічних інтересів; та сформує засоби та способи протидій економічній злочинності та ліквідації її наслідків.

Наслідки економічної злочинності для національної економічної безпекиє настільки вагомими, що їх можна визначати як детермінанти дієвості економічної системи держави та можливості її існування в майбутньому. Економічна злочинність та врегулювання економічних інтересів різних соціальних груп стали своєрідним каталізатором формування держави та інститутів державного управління. Відповідно до цього мають трансформуватися методи боротьби з економічною злочинністю, розвиватися правові механізми державного управління, видозмінюватися діяльність державних інституцій, на які покладено функції виявлення економічних злочинів та притягнення до відповідальності винних осіб. Економічні злочини мають вагоме значення з позиції державного управління національною безпекою, а отже, мають вивчатися в усіх аспектах прояву від мотивудо встановлення відповідальності. Першооснова економічних злочинів лежить в інтересах людини.

У статті досліджено економічну злочинність у контексті ідентифікації стимулів здійснення економічних злочинів людиною. В результаті проведеного аналізу з позиції оцінки мотивів людини та соціальних груп до економічних злочинів було згруповано, а також візуалізовано потреби людини як фізичної істоти та соціально-економічного агента. Доведено, що людина безпосередньо впиває на розвиток суспільства та економіки. В окремих випадках такий розвиток може відбуватися як екстенсивним, так і інтенсивним шляхом, або ж може відбуватися падіння
\end{abstract}


показників розвитку різних систем функціонування суспільства, в статті було розглянуто особливості зазначеної взаємодії. Було виявлено найбільш поширені в Україні та світі економічні злочини, що становлять найбільшу загрозу національній безпеці. Розроблено матрицю задоволення потреб людини через економічні злочини відповідних видів, зокрема: недобросовісна конкуренція, легалізація коштів отриманих злочинним шляхом та фінансування тероризму, рейдерство, нецільове використання бюджетних коштів, фіскальні злочини, корупція. Проаналізовано економічні злочини з позиції економічного інтересу.

The purpose of public administration is to regulate economic interests in society, which will in some way prevent economic crime, ensure the rule of law, which avoids conflicts of economic interests; and form the means and methods of counteracting economic crime and eliminating its consequences.

The consequences of economic crime for national economic security are so significant that they can be defined as determinants of the effectiveness of the economic system of the state and the possibility of its existence in the future. Economic crime and the settlement of economic interests of various social groups have become a kind of catalyst for the formation of the state and institutions of public administration. Accordingly, the methods of combating economic crime should be transformed, legal mechanisms of public administration should be developed, the activities of state institutions, which are entrusted with the functions of detecting economic crimes and bringing perpetrators to justice, should be changed. Economic crimes are important from the standpoint of public administration of national security, and therefore should be studied in all aspects of the manifestation from the motive to the establishment of responsibility. The primary basis of economic crime lies in the interests of man.

The article examines economic crime in the context of identifying incentives for economic crimes by individuals. As a result of the analysis from the standpoint of assessing the motives of people and social groups to economic crimes, the needs of man as a physical being and a socio-economic agent were grouped and visualized. It is proved that a person directly affects the development of society and economy. In some cases, such development may occur both extensively and intensively, or there may be a decline in the development of various systems of society, the article considered the features of this interaction. The most common economic crimes in Ukraine and the world, which pose the greatest threat to national security, were identified. A matrix for meeting human needs through economic crimes of the relevant types has been developed, in particular: unfair competition, money laundering and terrorist financing, raiding, misuse of budget funds, fiscal crimes, and corruption. Economic crimes from the standpoint of economic interest are analyzed.

КлючоВі слоВа: економічна злочинність, економічні інтереси, економічнізлочини, потреби людини, держаВна безпека, державне управління.

Keywords: economic crime, economic interests, economic crimes, human needs, state security, public administration.

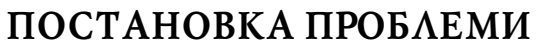

Об'єктом дослідження в сорері публічного управління та адміністрування (державного управління), що не втрачає свою актуальність, $є$ економічна безпека держави. Економічна сорера пропонує усі сорери державного управління, а від її рівня залежать інші сорери національної безпеки. Питання економічної безпеки $є$ не новим для наук з державного управління, проте в здебільшого дане питання розглядалося за сорерами реалізації економічної політики. На сьогодні вкрай гостро стоїть питання забезпечення економічної безпеки держави в умовах високого рівня економічної злочинності. "Минуле XX століття стало не лише століттям стрімкого науково-технічного прогресу, але й століттям жорсткого винищення людей у військових конфліктах, а також високого росту злочинності. Занепокоєність населення майже постійним зростанням злочинності в усьому світі є сигналом для більш інтенсивного наукового дослідження зазначеної проблеми. Масштаби цього явища досі не вивчені через його високу латентність (тобто схованої, незареєстрованої частини). Прямий та непрямий економічний збиток від злочинності в різних країнах складає декілька відсотків ВВП" [1, с. 6].

Вищезазначене актуалізує науковий пошук у контексті розширення об'єкта пізнання наук державного управління в сорері забезпечення економічної безпеки держави. Так, сьогодні потребують уточнення межі державної політики в сорері боротьби з економічною злочинністю як загрози національній безпеці держави. 


\section{AHА $\Lambda$ I3 ОСТ АHНIX АОС $\triangle \mathrm{IAЖEHЬ}$ ТА ПУБАІКАЦІЙ}

Питання боротьби з економічною злочинністю як загрози економічній безпеці держави піднімалися в працях вітчизняних та зарубіжних вчених, зокрема: Бойко А.М. [5], Іващенко В. [10], Безрутченко В.С. [3], Беницкий А.С., Розовский Б.Г., Якимов О.Ю. [4], Франчук В.В. [32], Юртаєва К.В. [33], Мельник В., Гаруст Ю. [19], Мельничук Т.В. [20], Ромен О. [28], Кальман О.Г. [13], Базуряк І.М. [2], Пилипенко Н.В. [25], Кравчук С. [14], Кузнецова Н.Ф. [16], Петров Э.И., Марченко Р.Н., Баринова Л.В. [24], Рогов И.И. [27], Йосипів Ю.Р. [12]. Так, економічна злочинність стала об'єктом наукових досліджень у різних сферах наукового пізнання: економічні, юридичні, психологічні, соціальні науки та науки з державного управління.

\section{META CTATTI}

Метою дослідження $є$ висвітлення економічної злочинності в контексті ідентифрікації стимулів здійснення економічних злочинів людиною. Це дозволить переглянути державну політику в контексті уникнення причин економічної злочинності та формування комплексу заходів з розвитку безпечної економічної системи держави.

\section{ВИК ААА ОСНОВНОГО МАТЕРІААУ АОС АІАЖЕННЯ}

Економічна злочинність як загроза національній економічній безпеці характерна різним економічним та політичним системам. Сторінки економічної історії свідчать, що жодна існуюча в світі економічна система не змогла уникнути економічної злочинності, жодна політична система не змогла задовольнити інтереси різних соціальних груп для уникнення економічної злочинності.

Дослідник проблем економіки злочинності Андрієнко Ю.В. зазначає, що "злочинність як антисуспільне явище виникло на зорі людства. Як добре відомо із одного із найдавніших історичних документів про історію людства - Старого Завіту, третя людина на землі Каїн - через почуття заздрощів вбив четверту людину - свого брата Авеля. 3 тих пір винищення людиною собі подібних за своїми масштабами зовсім не поступалося подібному поширеному явищу в тваринному світі, яке керується раціональним інстинктом, а не розумом" $[1$, с. 6$]$.

Історично склалося так, що економічна злочинність супроводжує розвиток людства ще з первісного ладу, а саме з часів об'єднання общин в різні види формувань. Такі фрормування в результаті стали основою фрормування державності та виникнення перших держав у світі. Сьогодні не можливо уявити, яким би був стан економічно злочинності, якби держава не виконувала правоохоронну функцію та не встановлювала обмеження щодо економічної діяльності та вплив на неї різних стейкхолдерів. Вважається, що першою сукупністю правових норм щодо економічної злочинності були Закони Хаммурапі в стародавньому Вавилоні. Так, статті 6 126 Кодексу Законів Хамураппі передбачають регулювання економічної діяльності, зокрема захист права власності. Зазначеними законами встановлено не лише правила економічної діяльності, але й види покарань за їх порушення.

У подальшому з розвитком торгівлі та різних видів економічної діяльності економічна злочинність набувала різноманітних форм та сорер поширення. Якщо ще десятиліття тому найбільш поширеними видами економічної злочинності було ухилення від сплати та мита, то сьогодні економічні злочини пов'язанні із фінансовими махінаціями із використанням інформаційно-комп'ютерних технологій. Сучасні цифрові технології дозволяють як уникнути та попередити певні види економічних злочинів, так і дозволяють їх реалізацію за умови низького рівня кібербезпеки суб'єктів господарювання.

Відповідно до цього мають трансорормуватися методи боротьби з економічною злочинністю, розвиватися правові механізми державного управління, видозмінюватися діяльність державних інституцій, на які покладені фрункції виявлення економічних злочинів та притягнення до відповідальності винних осіб.

Першооснова економічних злочинів лежить в інтересах людини. "Велику роль в економічному житті суспільства грають економічні відносини між людьми. Від досконалості економічних відносин залежить не лише розвиток способу виробництва, але й соціальна рівновага в суспільстві та його стабільність. 3 їх змістом прямо пов'язане вирішення проблеми соціальної справедливості, коли кожна людина та соціальна група отримує можливість користуватися різного роду соціальними благами в залежності від суспільної корисності своєї діяльності, її необхідності для інших людей, суспільства, держави, зокрема для реалізації їх економічних інтересів. Економічні інтереси є об'єктивними мотивами діяльності людей, що відображає їх місце в системі суспільного виробництва" [23, с. 45].

Варто зауважити, що представлена теза характеризує здебільшого ідеальне суспільство, проте в ряді випадків досягнення економічних інтересів може стати мотивом здійснення економічного злочину. В кримінології зазначені категорії знаходяться в тісному зв'язку: "конкретний вольовий акт, підкоряючись закону причинності, виникає в результаті тісної взаємодії трьох причинних зв'язків. Людина стає на шлях протиправної поведінки, намагаючись задовольнити у такий спосіб свої потреби та інтереси, відбувається формування мотивації. Певним поштовхом, "каталізатором" виступатиме конкретна ситуація, в якій людина перебувала до вчинення протиправних дій. Передуючи акту злочинної поведінки, відбувається прогнозування можливих наслідків реалізації бажання, яке виникло, планування поведінки із врахуванням реальної обстановки і власних можливостей, у людини більш-менш точно моделюється майбутній вчинок" [18].

Людина та її поведінка має стати точкою відліку наукового дослідження проблем державної політики в сфрері боротьби з економічною злочинністю як загрози національній економічній безпеці. Варто наголосити, що до економічних злочинів людину чи групу людей або ж цілі соціальні інститути спонукають сукупність фракторів, які визначаються економічним інтересом. "Інтерес, яким би він на перший погляд був, завжди є суто людською характеристикою. Інакше кажучи, він є проявом самої 
людини в суспільстві, а тому за своїм змістом $€$ суто індивідуальним" [23, с. 55].

Економічний інтерес супроводжує функціонування людини на різних етапах розвитку соціально-економічних відносин. Фактично інтерес $€$ базою формування економічних відносин у суспільстві та становить їх змістовну наповненість, визначаючи властивості економічних відносин певного суспільства зважаючи на певний етап історичного розвитку.

Кушнарьов І.В. зазначає, що "перш за все необхідно звернути увагу на те, що будь-які соціальні зв'язки виникають внаслідок того, що кожна особа прагне реалізації своїх потреб, інтересів і цінностей, які у сукупності складають мотиваційну сферу свідомості людини. Завдяки суперечливому поєднанню в людині властивостей відкритої та закритої систем її свідомість $€$ одночасно суб'єктивним відображенням об'єктивної дійсності та внутрішнім світом особистості. Звісно, кожна людина протягом життя піддається впливу різноманітних фракторів, але вони проходять через свідомість людини і не зумовлюють фатально та однозначно вибір індивідом того чи іншого варіанта поведінки. Можна сказати, що всі соціальні явища і процеси, як позитивні, так і негативні, $€$ результатом поєднання численних людських рішень, і так звані соціальні закономірності відображають повторюваність рішень у схожих умовах. Разом з тим, кожна особа приймає рішення особисто, на основі власних цінностей і переконань, і досить часто приймає такі рішення всупереч науково встановленим закономірностям" [17, с. 90].

Саме тому досліджуючи економічну злочинність 3 позиції державного управління національною безпекою держави варто враховувати цілу сукупність фракторів, які визначають незаконну економну активність людини.

Здебільшого економічні інтереси характеризують досягнення певного рівня потреб за пірамідою потреб Абрагама Маслоу. Американський психолог ще в 1943 р. в одній із публікацій представив результати свого дослідження потреб людини. "А. Маслоу доводив, що в поведінці людини домінують потреби найнижчого незаповненого рівня, і людина надає їм пріоритет лише тоді, коли потреби нижчого порівняно з ним рівня задоволені. Це означає, що людина починає піклуватися про свою безпеку тоді, коли задовольнить найнагальнішу потребу - біологічного виживання. Прагнення до любові, поваги виходить на чільне місце у разі, коли людина забезпечена матеріально, має захист від природних і суспільних загроз та перспективу майбутнього (сім'я, здоров'я, власність). Відповідно питання гідності, поваги, а тим більше самореалізації не належать до пріоритетних без задоволення потреб попереднього рівня" [7, с. 12-13]. Усі потреби вчений визначив за п'ятьма ієрархічними рівнями та визначив, що рух до потреб вищого рівня неможливий без досягнення потреб нижчих рівнів. Варто зазначити, що власне піраміда потреб Маслоу як термін в економічних та психологічних дослідженнях виник пізніше, а вченими було доповнено піраміду іншими рівнями потреб людини. В нашому випадку ми зупинимося на класичному розумінні потреб та спробуємо визначити напрями їх досягнення 3 позиції вчиненні економічних злочинів, тобто дослідимо економічний злочин як засіб задоволення відпові- дних потреб окремою людини та економічних інтересів суспільних інститутів.

"Економічні інтереси людей виступають як спонукальні сили їх економічної діяльності. В процесі цієї діяльності вони намагаються реалізувати свої інтереси, які тісно пов'язані з їх потребами, хоча й відрізняються від них. Потреби людей - це прояв об'єктивної необхідності в створенні умов їх життєдіяльності. Це потреби в харчуванні, теплі, одязі, житлі та інші. Це можливо сказати і про духовні та інші потреби. В свою чергу в інтересах виражені шляхи та способи задоволення потреб. Це стосується інтересів людей та соціальних груп" [9].

Зазначимо, що одним із способів та шляхів досягнення певного інтересу як людиною так і соціальної групою можуть бути економічні злочини. Цікавим $€$ той фракт, що якщо в класичному розумінні економічні злочини направлені на досягнення економічно інтересу, що стосується незаконної економічної вигоди, то окремі види економічної злочинності направлені на досягнення економічних інтересів, що визначають статус особи або групи осіб у суспільстві. Це стосується в першу чергу мафріозних формувань в Сицилії, основною ціллю яких на початковому етапі була власна безпека, а не економічна вигода.

"B XIV-XVIII століттях на Сицилії відбулося укрупнення земельної власності та сільських поселень. При цьому зв'язки між селами слабшали, ринки концентрувалися у містах, куди перебиралися й власники землі. Панування землевласників над аграрними працівниками посилювалося технологічною нерозвиненістю. Але імператив капіталістичного розвитку залучав землевласників в ринкові відносини та вимагав інституційних регуляторів. Довгий час поширена політика іспанських Габсбургів ("розділяй та пануй") створила атмосфреру недовіри, що відобразилося на звичках людей розраховувати лише на родичів та близьких людей. До того ж сицилійці, маючи справу із правосуддям, традиційно користувалися посередницькою допомогою, не довіряючи адміністративній владі. А в умовах багатьох суспільних змін та порушень звичайних зв'язків права сільськогосподарських суб'єктів виявилися незахищеними. Суспільство задовольнило дану потребу в особі управляючих та служби охорони фреодальної земельної власності - демобілізованих гарібальдійців, бандитів та колишніх ув'язнених. Саме довіра громадянами протекції своєї власності стало на думку Раймондо Катанзаро, вирішальним моментом росту мафії. Люди прагнули до таких гарантій, яких знали б, поважали та яких би оберігалися потенційні бандити або всі ті, хто є загрозою їх власності" [30, с. 128].

Фактично забезпечення економічних інтересів може служити мотивом економічної діяльності особи або групи осіб, що реалізується через законну або незаконну економічну діяльність. Досить влучно взаємозв'язок мотивації та досягнення економічних інтересів охарактеризував Нестенко А.: "Результатом визнання об'єктивних економічних інтересів $\epsilon$, зокрема, виникнення певних мотивів діяльності людей, їх бажань, прагнень та суб'єктивної зацікавленості в тих чи інших діях. Дана суб'єктивна зацікавленість людини чи соціальної групи в будь-чому виступає як більш чи менш повний прояв в 
їх індивідуальному або груповому визнанні їх об'єктивних інтересів. Так, суб'єктивна зацікавленість людей в підвищенні ефективності своєї економічної діяльност відображає їх об'єктивні економічні інтереси, закладені в існуючій системі оплати праці. При цьому зазначена об'єктивна матеріальна зацікавленість суб'єктивна лише за фрормою, оскільки проявляється як момент внутрішнього світу суб'єкту, його свідомості. За змістом вона об'єктивна, оскільки відображає те, що існує в об'єктивній економічній реальності" [22].

Таким чином, з позиції оцінки мотивів людини та соціальних груп до економічних злочинів усі види потреб можна згрупувати так:

— потреби людини, які стосуються забезпечення іії фрізіологічного розвитку;

— потреби людини, що пов'язанні із її становищем у суспільстві.

Відповідно до цього людину варто розглядати як біологічну істоту та як члена суспільства. Виходячи з цього усі рівні піраміди потреб можливо представити у вигляді двох напрямів, а саме:

- ті які характеризують людину як фрізичну істоту;

- ті які характеризують людину як соціально-економічного агента.

"Для того щоб зрозуміти сутність цих взаємин, з різноманітних процесів і явищ потрібно виділити постійно діючі фрактори, які лежать в основі існування людської спільноти. У людини як у біологічної істоти є певний набір вітальних (життєвих) потреб, як у члена суспільства - соціальних (інформаційних), на певному етапі розвитку формуються економічні потреби. Задоволення цих потреб є основним стимулом людської діяльності як окремої людини, так і спільноти людей загалом. Базовими, основоположними є вітальні потреби, без задоволення яких неможлива діяльність і розвиток людини як розумної істоти. Необхідність співіснування привела до появи правил виробництва, обміну, розподілу і споживання, що зумовили виникнення і закріплення соціально-економічних потреб. Економічні відносини - сукупність відносин між людьми з питань виробництва, розподілу, обміну та споживання матеріальних і нематеріальних благ. У міру історичного ускладнення суспільства ці відносини значно змінювалися, від діючих окремо натуральних господарств до того, що зараз ми називаємо ринком, від прямої взаємодії споживач-виробник, до соціально-опосередкованого покупець-продавець" [21, с. 213].

Фактично потреби спонукають до економічної активності людини в суспільстві. Кожен вид потреб характеризує людину як фрізичну істоту (потреби в безпеці та фрізіологічні потреби) та як соціального агента (потреба в самореалізації, потреби у визнанні та потреби в соціалізації). Усі види потреб пов'язанні між собою та можуть забезпечувати одне одного. Крім того, потреби людини як соціального агента та як фрізичної особи спонукають її до економічної активності, яка в свою чергу знаходиться на перетині інтересів різних осіб.

Фокін Н.І. вказує, що "потреба - базове економічне поняття. У цій якості під потребою розуміють внутрішній мотив, що спонукає до економічної діяльності. Що в основі мотиву? Недолік чогось необхідного для підтримки життєдіяльності і розвитку особистості, підприємства, економіки в цілому. Коли потреби усвідомлюються, вони виступають як економічні інтереси" [31]. Потреби та інтереси людини визначаються суспільними відносинами, природно-кліматичними умовами та сукупністю інших соціальних чинників. "Функціонування потреби можна представити у вигляді прямого і зворотного зв'язку зі середовищем: середовище впливає на потребу, а потреба, у свою чергу, впливає на середовище" [26, с. 112]. Це визначає особливості досягнення потреб через економічну активність людини.

Візуалізація потреб людини як фрізичної істоти та соціально-економічного агента представлено на рисунку 1.

Економічна активність людини в суспільстві відбувається двома шляхами: законний та незаконний. Так при вивченні окремого економічного злочину забезпечення відповідної потреби виступатиме мотивом його скоєння, а при вивченні економічної злочинності в цілому визначатиме економічний інтерес, що переслідує відповідний суспільний інститут.

У своїх попередніх працях автором було представленні результати подібного дослідження лише в контексті впливу економічної активності людини на навколишнє середовище. Так, у дослідженні [34] було обгрунтовано так: "В цілому, можна говорити, що людина як економічний агент це тандем людини як фрізичної особи з сукупністю мотивів та потреб, які розвивалися людством протягом відповідних соціально-економічних трансформаційних епох... Людина одночасно як складова біофізичних систем і як чинник впливу на них, постійно взаємодіє і нерозривно пов'язані один з одним: дії людини впливають на біофізичну систему, змінюючи її первісний стан і викликаючи оборотні та необоротні перетворення; біофізичні сили та їх зміни впливають на добробут людини, і люди реагують, в свою чергу на ці сили". Подібним чином людина впиває ї на розвиток суспільства та економіки. В окремих випадках такий розвиток може відбуватися як екстенсивним так і інтенсивним шляхом, або ж може відбуватися падіння показників розвитку різних систем функціонування суспільства. Розглянемо особливості зазначеної взаємодії в контексті наступних положень:

- потреби людини в залежності від їх прояву визначають напрями економічної активності. Причому як фрізіологічні потреби, так і потреби пов'язані із соціальною реалізацією залежать від сукупності фракторів, які можна згрупувати наступним чином: специфріка суспільних відносин та природно-кліматичні умови. Варто зазначити, що як специфіка суспільних відносин, так і природно-кліматичні умови визначають як структуру потреб, так і процес їх забезпечення через економічну активність людини. Так, суспільні відносини та природно-кліматичні умови впливають на економічну систему, визначають її інституційний розвиток та галузеву спрямованість, механізми та методи реалізації економічних процесів, а також способи та методи реалізації економічної активності через економічні злочини. Сфери здійснення економічних злочинів залежать від зазначених фракторів. Наприклад, для держав, які володіють вагомими запасами природних ресурсів, характерні економічні злочини пов'язані із незаконним видобутком 


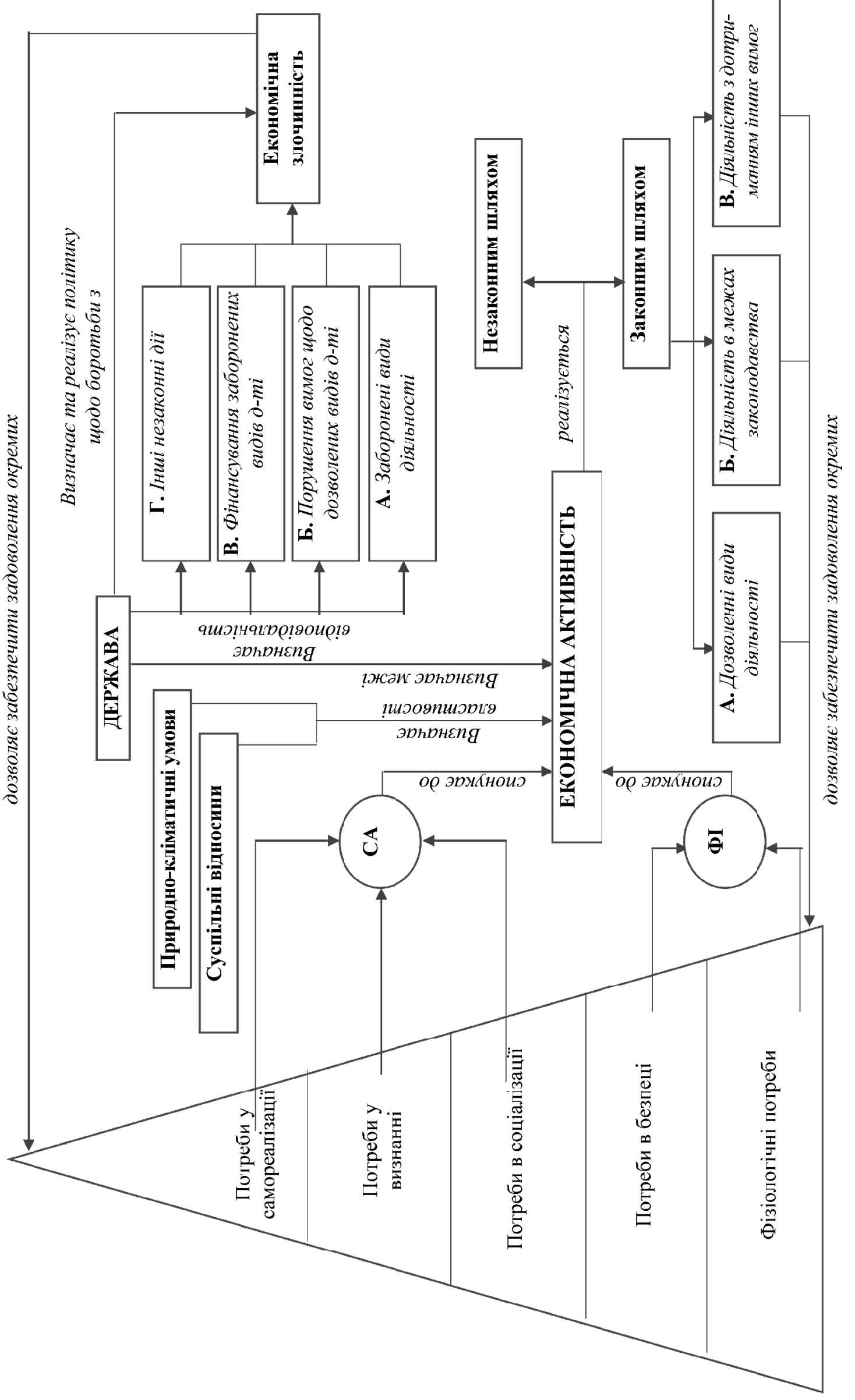

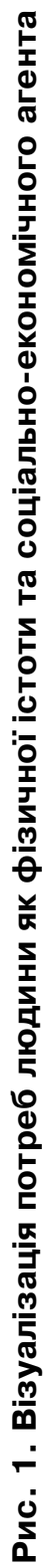


природних ресурсів, що характерно для Житомирської та Рівненської областей в контексті незаконного видобутку бурштину. В залежності від цифровізації суспільних відносин в суспільстві залежить механізми та способи здійснення економічних злочинів. Так, для країн з високим рівнем цифровізації суспільних відносин характерні економічні злочинні в кіберпросторі. Важливим фактором $є$ також віросповідання, адже закладає ментальні особливості поведінки людини, адже ортодоксальні положення тих чи інших релігій можуть впливати на поведінку людини та її сприйняття дозволеного та забороненого. Особлива перевага релігійного фактору характерна для країн зони поширення Ісламу. "Ісламська економічна доктрина пропагує три основні принципи розвитку соціально-економічних відносин в суспільстві: різноманіття фрорм власності, обмеження економічної активності, соціальна справедливість. Зазначені принципи виведені на основі базових положень ісламу, які $\epsilon$ обов'язковими для виконання кожним суб'єктом господарювання, та повинні забезпечити відповідність економічної системи положенням ісламу" [11, с. 8]. Так, в окремих мусульманських країнах важливе значення надається Шаріату як інституційної основі фрормування цивільного законодавства та економічної системи країни. Важливе значення серед суспільних факторів $\epsilon$ економічна, політична та культурна переорієнтація держави. Це характерно для країн пострадянського простору та тих економічних злочинів які здебільшого притаманні їм в 90-х роках. "В даний час ситуація складається таким чином, що норми традиційної економічної культури не працюють, нова культура ще не сорормована. Практичного досвіду для реалізації нових рис економічної культури немає. Стереотипи ринкової поведінки ще не сформовані. Зміни в масовій економічній свідомості проявляються в двох фрормах. Перша фрорма культурної переорієнтації - засвоєння нових стереотипів економічної поведінки, відповідних ринкової економіки, культури цивілізаційних країн світу. Дійсно, за короткий термін з початку ринкових реформ населення країни зіткнулося з безліччю нових стереотипів поведінки. Друга форма протилежна першій, полягає в обході законів, цивільних заборон, порушення норм. Певні стереотипи поведінки виникають як реакція на об'єктивні умови, які виступають наслідком політики. Зіткнення нових стандартів поведінки в економіці з традиційними моделями, які супроводжують цей процес, конфрлікти вимагають серйозного наукового осмислення сутності френомену, умов, фракторів, напрямів його трансфрормації. Звісно ж необхідним використовувати при аналізі даного явища інституційний підхід" [15, с. 11-12]. Саме тому при дослідженні проблем державного управління у сорері протидії економічній злочинності варто зважати та специфіку суспільних відносин та природно-кліматичних умов;

- економічна активність людини з позиції забезпечення відповідного набору потреб може реалізуватися законним та незаконним шляхом. Це залежить від середовища, в якому знаходиться людина, ії мотивів, ментальності, релігійності, національної ідентичності. До законних шляхів забезпечення потреб відносимо: поперше, дозволені види діяльності; по-друге, діяльність в межах законодавства; по-третє, діяльність із дотри- манням інших вимог. Дозволеними видами діяльності людини є усі види діяльності окремої людини, групи людей, суб'єктів господарювання, що дозволені на законодавчому рівні. Формування переліку видів дозволених видів діяльності фрізичних чи юридичних осіб визначається національним законодавством, що в свою чергу знаходиться під впливом національної ідентичності. Наприклад, такий перелік в країнах зони поширення Ісламу буде значно ширший ніж в країнах Заходу, зокрема, що стосується фрінансового сектору та діяльності банківських установ. Кожен вид дозволеної діяльності як окремої людини так і суб'єктів господарювання знаходиться в певних законодавчих обмеженнях, які можуть визначатися різними галузями законодавства, наприклад: господарським, податковим, трудовим, екологічним, міжнародним. Крім того, обмеження в діяльності суб'єктів господарювання можуть бути визначені специфрікою її реалізації в певній галузі національної економіки. Окрім вищезазначених особливостей, задоволення потреб законними шляхами можуть бути обмежені не лише національним законодавством, але й міжнародними угодами чи регіональними підзаконними актами. Загалом законні шляхи досягнення потреб є основою економічної активності людини.

До незаконних шляхів забезпечення інтересів та потреб людини чи групи осіб належать: заборонні види діяльності, порушення вимог щодо дозволених видів діяльності, фрінансування заборонених видів діяльності та інші незаконні дії. Говорячи про заборонні види діяльності, варто віднести ті види, що здійснюються особою або групою осіб та є: по-перше, незаконними видами діяльності загалом (наприклад, виробництво та реалізація наркотиків, торгівля людьми, проституція та інше); по-друге, забороненими для конкретних суб'єктів в частині встановлених обмежень податковим законодавством, галузевим законодавством (наприклад, у сфрері медицини, лісокористування, землекористування, видобуток корисних копалин та інше); по-третє, види діяльності, які в цілому є дозволеними в державі, але відповідний суб'єкт не отримав дозволу на її реалізацію. Зазначимо, що в даному контексті фрормування законодавства, яке регулює економічну діяльність в державі залежить від ряду ментальних, релігійних та національних особливостей. Цікавим прикладом $є$ країни зони поширення Ісламу, в яких важливе значення серед інститутів регулювання господарської діяльності має Шаріат, що визначає наступні важливі економічні категорії: гарар - уникнення будь-якого роду інфрормаційної асиметрії на ринку; мейсір - головним чинником отримання доходу мають стати не фрінансові операції, а виробництво та торгівля; ріба - заборонна банківського відсотку та інших видів діяльності. Важливою складовою незаконних шляхів забезпечення потреб та інтересів особи є порушення вимог щодо дозволених видів діяльності. Так, до кожного із дозволених видів діяльності встановлюються вимоги, які можуть визначатися ліцензійним законодавством, наприклад щодо реалізації медичних послуг, освітніх послуг, видобутку корисних копалин та інше. Крім того, вагоме значення в здійсненні дозволених видів діяльності має податкове законодавством. Відповідно особа чи група осіб задля збільшення ймовірності задоволення свої потреб та інте- 
Таблиця 1. Матриця задоволення потреб людини через економічні злочини відповідних видів

\begin{tabular}{|c|c|c|c|c|c|}
\hline \multirow[t]{2}{*}{ Види економічних злочинів } & \multicolumn{5}{|c|}{$\begin{array}{c}\text { Потреби людини } \\
\text { за пірамідою Маслоу }\end{array}$} \\
\hline & $\Pi 1^{1}$ & $\Pi 2^{2}$ & П $\mathbf{3}^{3}$ & \begin{tabular}{|l|}
$\Pi 4^{4}$ \\
\end{tabular} & I $5^{5}$ \\
\hline Недобросовісна конкуренція & \pm & & \pm & \pm & \\
\hline $\begin{array}{l}\text { Легалізація коштів отриманих } \\
\text { злочинним шляхом та } \\
\text { фінансування тероризму }\end{array}$ & \pm & & & \pm & \pm \\
\hline Рейдерство & \pm & & & & \\
\hline $\begin{array}{l}\text { Неиільове використання } \\
\text { бюджетних коштів }\end{array}$ & \pm & & & & \\
\hline Фіскальні злочини & \pm & & & & \\
\hline Корупція & \pm & & \pm & & \\
\hline
\end{tabular}

1 Фізіологічні потреби.

2 Потреби в безпеці.

3 Потреби в соціалізації.

4 Потреби у визнанні.

5 Потреби у самореалізації.

ресів може чинити відповідні дії щодо порушення відповідних законних та підзаконних актів, що в цілому визначає напрями здійснення економічних злочинів. Важливою складовою та особливо актуальною в сучасному світі $€$ проблема фрінансування незаконних видів діяльності. Прикладом цього $€$ фрінансування тероризму. За своєю суттю вчинення такого злочинного діяння як фрінансування тероризму окремою особою або групою осіб може визначати задоволення не лише матеріальної потреби, але й потреб вищого рівня, зокрема: потреби в соціалізації, потреби у визнанні, потреби у самореалізації. Адже, тероризм за своєю суттю може проявлятися у різних сорерах суспільного життя та переслідувати релігійні та націоналістичні мотиви. Складові інших незаконних дій можуть визначатися власне національними та релігійними особливостями.

Загалом незаконні шляхи досягнення потреб в економічній сорері становлять економічну злочинність. Важливу роль у змістовному наповнення економічної злочинності відіграє держава та уся система державного управління, враховуючи три гілки влади: законодавча, виконавча та судова. В цьому випадку держава виступає з трьох позицій: по-перше, визначає межі економічної активності особи або групи осіб, які в свою чергу $є$ основою ідентифрікації законних та незаконних шляхів задоволення потреб; по-друге, визначає та реалізує політику щодо боротьби з економічною злочинністю, а саме: фрормує систему нормативно-правового регулювання, визначає склад та структуру державних інститутів щодо боротьби з економічною злочинністю та формує напрями налагодження комунікації між ними; по-третє, визначає відповідальність осіб чи групи осіб за скоєні економічні злочини. Загалом держава як суспільний інститут формує ряд вимог до економічної активності людини, що не виникають самі по собі, а формуються певний період часу через взаємодію соціальних інститутів та еволюціонують у залежності від середовища. "Якщо пройшла локалізація деяких особливих фрорм взаємодії, то відбувається закріплення нового правила чи норми в рамках окремого великого інституційного співтовариства індивідів. При чому зазначене закріплення може бути як формальним (у вигляді окремих поста- нов, указів, рішень та інше), так і неформальним (у вигляді звички, загальноприйнятої норми, визначеної моделі поведінки). Тут можливі два варіанти розвитку: перший - правила та норми в результаті апробації демонструють свою неприйнятність для великої спільності і тому відкидаються більшістю, але можуть залишатися локальним, тобто вузько груповим правилом; другий правила та норми, що застосовуються на певній території, забезпечують ефективні взаємозв'язки суб'єктів господарювання і закріплюються як формальні правила" [23, с. 27]. Прикладами зазначеного можуть бути власне країни зони поширення Ісламу, Японія та Китай, де релігійні та ментальні норми лягли в окремі формальні норми, що представлені в законодавстві певних країн. Крім того, варто зазначити, що в окремих країнах заборонені види діяльності можуть прописуватися до дрібниць, а в інших бути узагальненими, що також залежить від ментальності та релігійних особливостей суспільства. Яскравим прикладом існування формальних та неформальних норм в контексті економічної злочинності $€$ виникнення мафії на італійському острові Сицилія. "Історично Сицилія перебувала на перехресті середземноморських торгових шляхів, займала важливе стратегічне положення і постійно піддавалася завоюванням. Більшу частину своєї історії населення острова прожило під владою інших держав - грецького, нормандського і іспанського. Феодальна Сицилія не мала власної державності, але її жителі, як відзначають багато дослідників, виробили неформальні механізми самоврядування, які дозволяли підтримувати багато в чому самостійне життя, яка не залежатиме від іноземного панування. Цей історичний фрон створив локальну субкультуру, характерною рисою якої була ворожість до держави і схильність покладатися на свої сили. Конфрлікти з державою набули особливої гостроти після переможної висадки на острові армії Джузеппе Гарібальді в 1863 р. і подальшого створення єдиної італійської держави" [6, с. 16]

Найбільш поширеними в Україні та світі економічними злочинами, що становлять найбільшу загрозу національній безпеці, $є$ такі:

- недобросовісна конкуренція;

- легалізація (відмивання) коштів отриманих злочинним шляхом та фрінансування тероризму;

- рейдерство;

- нецільове використання бюджетних коштів;

- фріскальні злочини;

- корупція.

Зазначені види злочини тоючи іншою мірою можуть задовольнити відповідні види потреб людини (табл. 1).

Таким чином, окремі види економічних злочинів направлені на забезпечення певних потреб людини. Проте, якщо розглядати економічні злочини не лише 3 позиції мотивів окремої людини, а в контексті суспільства в цілому, то варто вести мову про таку економічну категорію як економічні інтереси. В цьому контексті вважаємо, що сукупність потреб групи осіб, або суспільства в цілому становлять економічний інтерес. Економічний інтерес характерний майже для усіх суспільних інститутів, а в окремих аспектах також виступає інститутом. Дослідження економічних злочинів з позиції економічного інтересу найбільш повно визначає напрями 
фрормування державного управління як системи, що забезпечує врегулювання різних груп суспільних інтересів та визначає сукупність інтересів держави як соціального інституту. "У своєму родовому об'єкті доступ до сорери економічної діяльності слід визнати не лише відношенням виробництва, розподілу, споживання та обсягу матеріальних та нематеріальних благ, а в першу чергу інтересами держави та інших суб'єктів економічної діяльності, а також громадян, діяльність яких в економіці пов'язана з діяльністю публічно-правових освітніх та інших суб'єктів виробництва" [29, с. 206].

Вважаємо, що дослідження державного управління в сфері боротьби з економічною злочинністю повинно будуватися на врахуванні економічних інтересів різних суспільних інститутів. Адже здебільшого проблеми, пов'язанні із реформуванням системи боротьби із економічною злочинністю, не вирішуються або вирішуються лише частково через протиріччя різних елітних груп, які керуються своїми приватними інтересами. Так, узгодження економічних інтересів різних суспільних груп державною політикою дозволять встановити ефективні правила гри в економічній сфері, й відповідно сприятиме зниженню рівня економічної злочинності та ефективності боротьби з її наслідками. В цьому контексті погоджуємося із позицією Нікітова І.М., який зазначає, що "Не можливо не помітити, що самі процеси інституціоналізації, формування інститутів залежать від співвідношення сил в реалізації суперечливих економічних інтересів. Правила гри, правила якими регулюються економічні взаємодії та обмеження поведінки економічного суб'єкта, не будуть встановлені, а якщо й будуть прийняті, не стануть виконуватися, якщо не досягнуть необхідного погодження економічних інтересів" [23, с. 27].

3 метою досягнення економічних інтересів суспільні інститути вступають в економічні відносини, які регулюються системою державного управління. 3 цього приводу погоджуємося із Запускловою О.Є "Економічні інтереси людей виступають як безпосередній прояв їх економічний інтересів. Так економічні інтереси підприємця та найманого робітника прямо визначаються їх місцем в системі економічних відносин між ними. Інтерес першого - отримання максимальних прибутків, інтерес іншого - дорожче продати свою робочу силу та отримати, можливо, більшу заробітну плату. Економічні інтереси селянина, чи то фермер чи член колективного господарства, також визначається його місцем в системі існуючих економічних відносин. Це не відноситься до службовців - вчителі, лікарі, вчені, працівники сорери культури та інші. Зміст та направленість їх економічних інтересів визначається змістом існуючих економічних відносин та їх місцем в системі даних відносин" [9].

Таким чином, економічний інтерес являє собою систему суспільних відносин у сферах виробництва матеріальних благ та послуг, обміну, розподілу та споживання, що базується на відносинах власності, та дозволяє задовольнити відповідні види потреб особи, групи осіб, суспільних інститутів і так далі. Такі відносини завжди базуються на положенні економічної вигоди, яку отримають учасники суспільних відносин.
Економічний інтерес будучи інституційною структурою, що формує вектор розвитку соціально-економічних відносин, фрактично виступає фрактором розвитку економічної системи загалом. Кожна людина тим чи іншим чином $€$ носієм економічних інтересів, які досить часто можуть не відповідати економічним інтересам суспільства чи інших учасників економічних відносин. За таких умов досягнення економічних інтересів може відбуватися не об'єктивним чином, а через економічні злочини, а тому взаємодія інтересів може виступати як рушійною силою соціально-економічного розвитку, так і деструктивним елементом такого розвитку, що в результаті становить загрозу національним інтересам та національній безпеці держави.

Забезпечення врегулювання економічних інтересів усіх учасників суспільних відносин покладається на державу, яка відповідно тежє носієм економічних інтересів. Держава повинна забезпечити досягнення економічних інтересів різними учасниками суспільних відносин об'єктивним шляхом. Це в свою чергу дозволить сорормувати безпечне середовище як для учасників суспільних відносин, так і для держави в цілому, адже держава є носієм національних інтересів, які полягають у забезпеченні її суверенності, незалежності, цілісності. Економічна злочинність $€$ деструктивним елементом у забезпеченні економічних інтересів учасників суспільних відносин, від рівня якої залежить не лише безпека таких відносин та її учасників, але й національна безпека держави загалом. Фактично держава через механізми державного управління протидії економічній злочинності забезпечує безпеку учасників суспільних відносин як їх основоположної потреби, а тому є носієм економічних інтересів, задоволення яких дозволяє досягти відповідного рівня економічної безпеки.

Економічна безпека $є$ складовою національної безпеки, яка в свою чергу є забезпечуючим фрактором інших складових, а саме: військова безпека, продовольча безпека, екологічна безпека, інфрормаційна безпека держави. "Економічна безпека органічно включена в систему державної безпеки разом з такими її складовими як забезпечення надійної обороноздатності країни, підтримання соціального миру в суспільстві, захист від екологічних лих" [23, с. 74]. В цьому контексті спостерігається тісний взаємозв'язок між складовими національної безпеки, зокрема: високий рівень обороноздатності держави забезпечується високим рівнем розвитку економіки, а з іншого боку, належний рівень обороноздатності та розвиту економіки неможливо забезпечити в суспільстві, в якому відсутній соціальний консенсус та мають місце соціальні конфлікти, які пов'язані в тому числі із економічною злочинністю (корупція, фрінансові махінації, недобросовісна конкуренція, рейдерство та будь-які інші прояви тіньової економіки).

Прикладом $€$ низький рівень економічної безпеки держави, що призвів до окупації державних територій України в 2014 р. Крім того, низький рівень економічного розвитку становить загрозу таким складовим національної безпеки:

- інфрормаційна безпека. Низький рівень інфрормаційної захищеності призводить до фрінансових шахрайств із використанням інформаційно-комп'ютерних технологій. Крім того, варто наголосити, що в умовах 
поширення пандемії пов'язаної із вірусною інфекцією COVID-19, низький економічний розвиток сільських територій та їх ізоляція від інтернет-технологій призвели до неможливості отримання мешканцями адміністративних послуг, а такожгарантованих державою освітній послуг. Тобто низький рівень доходів не дозволяє мешканцям сільських територій використовувати сучасні інформаційно-комп'ютерні технології для отримання послуг, що гарантовані державою;

- екологічна безпека. Низький рівень економічного розвитку не дозволяє виробникам використовувати високотехнологічні екологічно безпечні засоби та предмети праці. Крім того, значна корупція в дозвільній системі сприяє безвідповідальному використанню природних ресурсів як державними, так і приватними підприємствами. Організована злочинність у Житомирській та Рівненській областях у сфері видобутку бурштину призвели до безповоротних екологічних втрат земельних ресурсів. Це загалом загрожує національній безпеці держави, адже правоохоронні органи не в змозі зупинити протиправну діяльність;

- військова безпека. Низький рівень економічного розвитку, що здебільшого спричинений корупцією та іншими видами економічної злочинності, не дозволяє в повною мірою фрінансово забезпечити оборонний сектор. Відсутність фінансової підтримки призвела до зниження української армії, а її відновлення досі не відбулося належним чином.

Відповідно лише при врахуванні усіх економічних загроз, у тому числі економічної злочинності, національній безпеці можна забезпечити суверенітет та незалежність держави. Адже економічна складова національної безпеки є гарантієюжиттєздатності суспільства. "Економіка країни являє собою одну із життєво важливих сторін діяльності суспільства, держави і особистості, i, отже, поняття національної безпеки буде порожнім словом без оцінки життєздатності економіки, її міцності при можливих зовнішніх і внутрішніх загрозах" [23, c. 71].

\section{ВИСНОВКИ}

У наукових працях вітчизняних та зарубіжних вчених економічна складова національної безпеки розглядається лише в контексті економічного потенціалу та ефективності його використання. В свою чергу тіньовий сектор визначений лише з позиції його оцінки та формування державної політики протидії. Такий підхід не повною мірою вирішує проблему забезпечення високого рівня економічного розвитку та його впливу на національну безпеку. Адже об'єктом державного управління має стати не тіньова економіка та механізми протидії ій, адже це лише результати економічних злочинів. Об'єктом державного управління має бути власне економічна злочинність та механізми запобігання та протидій.

Відповідно мета державного управління це: в першу чергу, врегулювання економічних інтересів в суспільстві, що дозволить певним чином запобігти економічній злочинності; в другу чергу, забезпечення дотримання правопорядку, який дозволяє уникнути конфрлікту економічних інтересів; в третю чергу, фрормування засобів та способів протидій економічній злочинності та ліквідації її наслідків.
Саме тому економічні інтереси є важливою економічною категорію при вивченні системи державного управління протидії економічній злочинності. Адже економічна злочинність щодо економічних інтересів має два прояви:

- по-перше, економічні злочини є засобом задоволення економічний інтересів особи або групи осіб;

- по-друге, економічна злочинність призводить до порушення економічних інтересів особи або групи осіб.

Загалом використовуючи інституційний підхід, можна вказати на те, що економічні злочини порушують економічні інтереси певних суспільних інститутів. Держава $є$ інститутом, що реалізує виконання інституційної угоди з приводу реалізації економічний інтересів, що являє собою особливу форму взаємодії інституцій. Держава встановлює правила та форми взаємодій суспільних інститутів з приводу економічний інтересів, які реалізуються через відповідні механізми державного управління. Від рівня економічної злочинності залежить національна безпека держави, адже здебільшого високий рівень економічної злочинності призводить до порушення економічних інтересів не лише суб'єктів економічної діяльності, але й інтересів держави та національних інтересів загалом.

\section{Література:}

1. Андриенко Ю.В. Экономика преступления: теоретическое и эмпирическое исследование определяющих фракторов преступности. Диссертация на соискание учёной степени кандидата экономических наук. Специальность 08.00.13 - математические и инструментальные методы экономики. Москва. 2004. 132 с.

2. Базуряк І. М. Економічна злочинність та її ознаки / / Науковий вісник ЛьвДУВС. - 2008. - № 2Ю. C. 279 .

3. Безрутченко В.С. Історичний шлях виникнення корупції, різноманітність поглядів на проблему визначення дефрініції цього явища [Електронний ресурс]. Режим доступу: http://www.nbuv.gov.ua /portal /Soc _Gum/bozk/18text/g18_32.htm

4. Беницкий А.С. Ответственность за легализацию преступно приобретенных доходов в уголовном законодательстве Украины и Российской Федерации: монография / А.С. Беницкий Б.Г. Розовский, О.Ю. Якимов. - Луганск, 2008. - 496 с.

5. Бойко А.М. Детермінація економічної злочинності в Україні в умовах переходу до ринкової економіки (теоретико-кримінологічне дослідження): монографрія / А.М. Бойко. - Львів: Видавничий центр ЛНУ імені Івана Франка, 2008. - 380 с.

6. Волков В. В. Мафияя в зеркале социологии, 2004. T. 5. № 3. С. $16-34$.

7. Дем'янчук О.П. Піраміда Маслоу як методологія пояснення політичної участі / О.П. Дем'янчук / / Наукові записки НаУКМА. - 2012. - Т. 134: Політичні науки. - С. 12-16.

8. Доступ домогосподарств України до інтернету у 2018 році (за даними вибіркового обстеження умов життя домогосподарств України): статистичний збірник. Державна служба статистики України. URL: http:// 
www.ukrstat.gov.ua/druk/publicat/kat_u/2019/zb/ 07/zb_Internet_2018.pdf

9. Зпускалова О.Е. Философрские проблемы экономической жизни общества. - Магнитогорск: Из-во Магнитогорского университета, 2000.

10. Іващенко В. Міжнародні та національні питання кримінальної відповідальності за фальшивомонетництво [Електронний ресурс]: Вісник академії управління MBC. - 1. 2007. - Режим доступу до журн.: http:// www.nbuv.gov.ua/portal/Soc_Gum/VAUMVS/200701.pdf

11. Ісламська модель бухгалтерського обліку в умовах глобалізації: напрями адаптації в Україні [Текст]: автореф. дис.... канд. екон. наук: 08.00.09 / Грицишен Д.О.; Житомир. держ. технол. ун-т. - Житомир, 2010. 21 с.: рис.

12. Йосипів Ю.Р. Деякі питання запобігання економічній злочинності// Актуальні проблеми діяльності ДСБЕЗ та підготовки фахівців для ії̈ підрозділів. 2012. - №02/03. - С. 123-126.

13. Кальман О.Г. Стан і головні напрями попередження економічної злочинності в Україні: теоретичні та прикладні проблеми: монографрія. - Х.: Гімназія, 2003. - С. 52.

14. Кравчук С. Основні причини поглиблення економічної злочинності в Україні / С. Кравчук / / Право України. - 2002. - № 11. - С. 54-55.

15. Кудинова Т.Н., Ярулин К.И. Социологический анализ теневой экономической деятельности: к постановке проблемы / / Вестник Тихоокеанского государственного университета. 2008. № 3 (10). С. 9-18.

16. Кузнецова Н.Ф. Кодификация норм о хазяйственных / Н.Ф. Кузнецова / / Вестн. Моск. ун-та. Сер. 11: Право. - 1993. - № 4. - С. 12.

17. Кушнарьов І.В. Причини та умови корупції / І.В. Кушнарьов / / Вісник Харківського національного університету внутрішніх справ. 2013. № 1. С. 88-96.

18. Медицький І.Б. Вплив соціальних фракторів на злочинність в умовах становлення незалежної Української держави. - Рукопис. Дисертація на здобуття наукового ступеня кандидата юридичних наук за спеціальністю 12.00.08 - кримінальне право та кримінологія; кримінально-виконавче право. - Київський національний університет внутрішніх справ. - Київ, 2006.

19. Мельник В., Гаруст Ю. Як в Україні карають за економічні злочини. Іскра. URL: http://iskra.kiev.ua/ iskra.html?act=article\&id=18371 (дата звернення: 01.09.2018).

20. Мельничук Т.В. Ціна економічної злочинності: проблемні аспекти визначення та застосування. Науковий вісник Міжнародного гуманітарного університету. Сер.: Юриспруденція. 2013. № 5. С. 189-193.

21. Монастырная Е.Е. Иерархия фракторов, мотивирующих деятельность человека в социально-экономической системе / Е.Е. Монастырная / / Вестник науки Сибири. - 2013. - № 1 (7). - С. 213-219.

22. Настенко А. Экономические интересы и экономические отношения // Экономика. - 1995. № 7-8.

23. Никитов И.Н. Экономические интересы: противоречия и согласования на разных уровнях. Диссертация на соискание ученой степени кандидата экономических наук. Специальность 08.00.01 - экономическая теория. Кострома. 2004. 160 с.
24. Петров Э.И. Криминологическая характеристика и предупреждение экономических преступлений: [учеб. пособие ]/ Э.И. Петров, Р.Н. Марченко, Л.В. Баринова. - М.: Академия МВД России, 1995. C. 12.

25. Пилипенко Н. В. Поняття та ознаки економічного злочину / / Вісник Запорізького юридичного інституту. - 2009. - № 1. - С. 60.

26. Рашидова С.С. Визначення феномену і поняття "потреба" / С.С. Рашидова / / Духовність особистості: методологія, теорія і практика. - 2015. - Вип. 5. С. 106-121. - Режим доступу: http://nbuv.gov.ua/ UJRN/domtp_2015_5_13

27. Рогов И.И. Проблемы борьбы с экономической преступностью (уголовно-правовое и криминологическое исследование ): дисс. ... д-ра юрид. наук: 12.00.08/ И.И. Рогов. - Алма-Ата: Казахск. гос. ун-т, 1991. C. 31.

28. Ромен О. Рік системі "ProZorro": 1001 можливість обдурити систему. URL: https://www.pwc.com/ ua/uk/press-room/assets/gecs_ukraine_ua.pdf (дата звернення: 01.09.2018).

29. Сидоров В.И. Классификация преступлений в сорере экономической деятельности // ВЭПС. 2017. №4. URL: https://cyberleninka.ru/article/n/klassifikatsiya-prestupleniy-v-sfere-ekonomicheskoydeyatelnosti-1 (дата обращения: 08.11.2020).

30. Синютин М.В. Институт мафии - частная собственность на применение насилия / М.В. Синютин // Журнал социологии и социальной антропологии. 2002. - Т.5 Вып. № 1. - С. 125-150.

31. Фокин Н.И. Экономика: В начале было Слово [Электронный ресурс]. - Режим доступа: http:// dictionary-economics.ru/word

32. Франчук В.В. Історико-правові аспекти виникнення деяких видів економічної злочинності / С.Я. Бурда / / Науковий вісник Львівського державного університету внутрішніх справ. Серія юридична. - 2009. Вип. 4. - С. 214-223.

33. Юртаєва К.В. Сучасні тенденції економічної злочинності в. Україні ХНУВС, Вісник кримінологічної асоціації України, № 2 (19), Харків,. 2018 р. С. 109-113.

34. levdokymov V., Oliinyk O., Grytsyshen D., Ksendzuk V., Nord G.The new geological epoch "anthropocene" as result of human economic activity. Comparative Economic Research. Central and Eastern Europe. Vol. 21, No. 3/2018. - P. 131-149.

\section{References:}

1. Andrienko, Yu.V. (2004), "Economics of crime: a theoretical and empirical study of the determinants of crime", Ph.D. Thesis, Economy, Moskva, Russia.

2. Bazurjak, I.M. (2008), "Economic crime and its symptoms", Naukovyj visnyk LjvDUVS, vol. 2.

3. Bezrutchenko, V.S. (2008), "The historical path of corruption, the diversity of views on the problem of defining this phenomenon", [Online], available at: http:// www.nbuv.gov.ua/portal/Soc_Gum/bozk/18text/ g18_32.htm (Accessed 30 Nov 2020).

$\overline{4}$. Benitskiy, A.S. Rozovskiy, B.G. and Yakimov, O.Yu. (2008), Otvetstvennost za legalizatsiyu prestupno priobretennykh dokhodov $v$ ugolovnom zakonodatelstve 
Ukrainy i Rossiyskoy Federatsii [Responsibility for the legalization of criminally acquired income in the criminal legislation of Ukraine and the Russian Federation], Lugansk, Ukraine.

5. Bojko, A.M. (2008), Determinacija ekonomichnoji zlochynnosti v Ukrajini v umovakh perekhodu do rynkovoji ekonomiky (teoretyko-kryminologhichne doslidzhennja) [Determination of economic crime in Ukraine in the transition to a market economy (theoretical and criminological research)], Vydavnychyj centr LNU imeni Ivana Franka, Ljviv, p. 380.

6 . Volkov, V.V. (2004), "Mafia in the mirror of sociology", vol. 5, no 3, pp. 16-34.

7. Dem'janchuk, O.P. (2012), "Maslow's Pyramid as a methodology for explaining political participation", Naukovi zapysky NaUKMA. vol. 134, pp. 12-16.

8. State Statistics Service of Ukraine (2018), "Access of households of Ukraine to the Internet in 2018 (according to a sample survey of living conditions of households in Ukraine)", [Online], available at: http://www.ukrstat.gov.ua/druk/publicat/kat_u/2019/zb/07/ zb_Internet_2018.pdf (Accessed 30 Nov 2020).

9. Zpuskalova, O.Ye. (2000), Filosofskie problemy ekonomicheskoy zhizni obshchestva [Philosophical problems of the economic life of society], Iz-vo Magnitogorskogo universiteta, Magnitogorsk, Russia.

10. Ivashhenko, V. (2007), "International and national issues of criminal liability for counterfeiting", Visnyk akademiji upravlinnja, vol. 1, [Online], available at: http:/ /www.nbuv.gov.ua/portal/Soc_Gum/VAUMVS/200701.pdf (Accessed 30 Nov 2020).

11. Ghrycyshen, D.O. (2010), "Islamic model of accounting in the context of globalization: areas of adaptation in Ukraine", Abstract of Ph.D. dissertation, Economy, Zhytomyr. derzh. tekhnol. un-t., Zhytomyr, Ukraine.

12. Josypiv, Ju.R. (2012), "Some issues of economic crime prevention", Aktualjni problemy dijaljnosti DSBEZ ta pidghotovky fakhivciv dlja jiji pidrozdiliv, vol. 02/03, pp. $123-126$.

13. Kaljman, O.Gh. (2003), Stan i gholovni naprjamy poperedzhennja ekonomichnoji zlochynnosti v Ukrajini: teoretychni ta prykladni problemy [The state and main directions of prevention of economic crime in Ukraine: theoretical and applied problems], Ghimnazija, Kharkiv, Ukraine.

14. Kravchuk, S. (2002), "The main reasons for the deepening of economic crime in Ukraine", Pravo Ukrajiny, vol. 11. pp. $54-55$.

15. Kudinova, T.N. and Yarulin K.I. (2008), "Sociological analysis of shadow economic activity: to the problem statement", Vestnik Tikhookeanskogo gosudarstvennogo universiteta, vol. 3, no 10, pp. 9-18.

16. Kuznetsova, N.F. (1993), "Codification of standards on economic", Vestn. Mosk. un-ta., Vol. 11, No 4, p. 12.

17. Kushnarjov, I.V. (2013), "Causes and conditions of corruption", Visnyk Kharkivsjkogho nacionaljnogho universytetu vnutrishnikh sprav, vol. 1, pp. 88-96.

18. Medycjkyj, I.B. (2006), "The influence of social factors on crime in the conditions of the formation of an independent Ukrainian state", Ph.D. Thesis, Law, Kyjivsjkyj nacionaljnyj universytet vnutrishnikh sprav, Kyiv, Ukraine.
19. Meljnyk, V. and Gharust, Ju. (2018), "How economic crimes are punished in Ukraine", [Online], available at: http:/ /iskra.kiev.ua/iskra.html?act=article\&id=18371 (Accessed 30 Nov 2020).

20. Meljnychuk, T.V. (2013), "The cost of economic crime: problematic aspects of definition and application", Naukovyj visnyk Mizhnarodnogho ghumanitarnogho universytetu. Vol. Jurysprudencija, vol. 5. pp. 189-193.

21. Monastyrnaya, Ye.Ye. (2013), "The hierarchy of factors motivating human activity in the socio-economic system", Vestnik nauki Sibiri, vol. 1, no 7, pp. 213-219.

22. Nastenko, A. (1995), "Economic interests and economic relations", Jekonomika, vol. 7-8.

23. Nikitov, I.N. (2004), "Economic interests: contradictions and agreements at different levels", Ph.D. Thesis, Economy, Kostroma, Russia.

24. Petrov, E.I. Marchenko, R.N. and Barinova, L.V. (1995), Kriminologicheskaya kharakteristika i preduprezhdenie ekonomicheskikh prestupleniy [Criminological characteristics and prevention of economic crimes], Akademiya MVD Rossii, Moscow, Russia.

25. Pylypenko, N.V. (2009), "The concept and signs of economic crime", Visnyk Zaporizjkogho jurydychnogho instytutu, vol. 1, $60 \mathrm{p}$.

26. Rashydova, S.S. (2015), "Definition of the phenomenon and the concept of "need"', Dukhovnistj osobystosti: metodologhija, teorija i praktyka, vol. 5, pp. 106121, available at: http://nbuv.gov.ua/UJRN/domtp_2015_5_13 (Accessed 30 Nov 2020).

27. Rogov, I.I. (1991), Problemy borby s ekonomicheskoy prestupnostyu (ugolovno-pravovoe i kriminologicheskoe issledovanie) [Problems of combating economic crime (criminal law and criminological research)], Kazakhsk. gos. un-t, Alma-Ata, Kazakhstan.

28. Romen, O. (2018), "Year of the ProZorro system: 1001 opportunities to deceive the system", available at: https://www.pwc.com/ua/uk/press-room/assets / gecs_ukraine_ua.pdf (Accessed 30 Nov 2020).

29. Sidorov, V.I. (2017), "Classification of crimes in the field of economic activity", VEPS, vol. 4, available at: https://cyberleninka.ru/article/n/klassifikatsiya-prestupleniy-v-sfere-ekonomicheskoy-deyatelnosti-1 (Accessed 30 Nov 2020).

30. Sinyutin, M.V. (2002), "Mafia Institute - Private Property to Use Violence", Zhurnal sotsiologii i sotsialnoy antropologii, vol. 5, no 1, pp. 125-150.

31. Fokin, N.I. (2009), "Economics: In the beginning was the Word", [Online], available at: http://dictionaryeconomics.ru/word (Accessed 30 Nov 2020).

32. Franchuk, V.V. and Burda, S.Ja. (2009), "Historical and legal aspects of some types of economic crime", Naukovyj visnyk Ljvivsjkogho derzhavnogho universytetu vnutrishnikh sprav, vol. 4, pp. 214-223.

33. Jurtajeva, K.V. (2018), "Current trends in economic crime in Ukraine", Visnyk kryminologhichnoji asociaciji Ukrajiny, vol. 3, no 19, pp. 109-113.

34. levdokymov, V. Oliinyk, O. Grytsyshen, D. Ksendzuk V. and Nord, G. (2018), "The new geological epoch "anthropocene" as result of human economic activity", Comparative Economic Research. Central and Eastern Europe, Vol. 21, No. 3, pp. 131-149.

Стаття надійшла до редакцї̈ 11.12.2020 p. 